\title{
Effects of Quaternary Ammonium Compounds with 0.1\% Sodium Hydroxide on Swine Vesicular Disease Virus
}

\author{
Junsuke SHIRAI, Toru KANNO, Toru INOUE, Satoru MITSUBAYASHI ${ }^{1)}$, and Reiji SEKI ${ }^{1)}$ \\ Department of Exotic Diseases, National Institute of Animal Health, 6-20-1, Josuihoncho, Kodaira, Tokyo 187 and ${ }^{11}$ Tamura \\ Pharmaceutical Co., Ltd., 1-4 Kanda Jinbocho, Chiyoda-ku, Tokyo 101, Japan
}

(Received 23 October 1996/Accepted 16 January 1997) ABSTRACT. The effects of quaternary ammonium compounds (QACs) with sodium hydroxide on swine vesicular disease virus (SVDV), an
enterovirus were studied. Didecyldimethylammonium chloride (DDAC) with $0.1 \% \mathrm{NaOH}$ showed a stronger effect against SVDV than
other QACs with $0.1 \% \mathrm{NaOH}$. The effect of DDAC with $0.1 \% \mathrm{NaOH}$ was strong at $40^{\circ} \mathrm{C}$. DDAC was effective against SVDV at pH
values around 11.0 , but not in the distilled water control. The effect of DDAC with $0.1 \% \mathrm{NaOH}$ was already observed at $1 \mathrm{~min}$ after
mixing of the DDAC with SVDV. Observation under an electron microscopy revealed that the probable mechanism of inactivation of
DDAC with $0.1 \% \mathrm{NaOH}$ is as follows: The virus particles were partially destroyed by $0.1 \% \mathrm{NaOH}$. DDAC gathered these affected
particles and formed a micelle, then SVDV lost its infectivity. From these results, QACs with $0.1 \% \mathrm{NaOH}$ are considered to be very
effective against SVDV representing enteroviruses. - KEY wORDS: disinfection, electron microscopy, $0.1 \% \mathrm{NaOH}$, quaternary ammonium
compound, swine vesicular disease virus.

Swine vesicular disease (SVD) is a contagious viral disease of swine indistinguishable in the field from footand-mouth disease (FMD) $[10,15]$. The pathogen of SVD is in the enterovirus group of picornaviruses [10] and its properties link it to the enteroviruses [10, 15]. SVD virus (SVDV) is resistant to the chemicals and disinfectants commonly used against FMD virus $[2,5]$.

Quaternary ammonium compounds (QACs) are used widely as disinfectants against pathogens including viruses. However, the activities against the pathogens are mainly studied only in bacterial pathogens because the QACs are not effective against almost all viruses [6]. Noll and Younger [11] classified viruses into three groups as follows: group A, enveloped viruses (e.g. Herpesviridae, Paramyxoviridae, Orthomyxoviridae); group B, small (20$30 \mathrm{~nm}$ ) non-enveloped viruses (e.g. Picornaviridae, Parvoviridae) and group C, other non-enveloped viruses (e.g. Adenoviridae, Reoviridae, Papovaviridae, Birnaviridae). The effect of QACs was found to be limited to the group A viruses $[6,9]$. However, recently, inactivation of infectious bursal disease virus (IBDV) by QACs with $0.1 \%$ sodium hydroxide $(\mathrm{NaOH})$ was reported [13]. IBDV belongs to the group $\mathrm{C}$ viruses and it is resistant to commonly used QACs.

Therefore, in this study, we examined the inactivation effect of QACs with $0.1 \% \mathrm{NaOH}$ on SVDV representing enteroviruses (group B, small non-enveloped viruses) and reveal the mechanism of the inactivation of viruses by QACs by morphological examination.

\section{MATERIALS AND METHODS}

Cell culture and viruses: IBRS-2 cell cultures were used in this study. SVDV strain J1 was isolated in Japan from vesicles of affected pigs [14]. It was plaque cloned 3 times and passaged many times in IBRS-2 cells. SVDV strain H/ 3'76 was isolated in Japan from the stool of a clinically normal pig [8]. It also was plaque cloned 3 times and passaged many times in IBRS-2 cells. Both virus strains were inoculated onto confluent monolayers of IBRS-2 cells after 1 day of cultivation, at a multiplicity of infection of 1 / 10. Infectious fluid was centrifuged at $3,000 \times \mathrm{g}$ for $10 \mathrm{~min}$ and stored at $-80^{\circ} \mathrm{C}$ until used as inoculum.

Virus titration: Virus titration was carried out by plaque formation in confluent monolayers of IBRS-2 cells grown in 30-mm-diameter 6-well plastic plates. Plaque formation was carried out according to the previous method [7]. The titrated viruses $(0.1 \mathrm{~m} l)$ were inoculated into each well. Plaque-forming units (PFU) in $\log 10$ per $0.1 \mathrm{~m} l$ of the material were determined from the dilution in which about 5 to 10 plaques had formed.

Effect of QACs on SVDV with or without $0.1 \% \mathrm{NaOH}$ : Three QAC-based commercial formulations were selected. The J1 and H/3'76 strains of SVDV were each mixed with equal volumes of didecyldimethylammonium chloride (DDAC) [1] diluted with distilled water to give final dilutions of $1 / 200,1 / 400,1 / 600$, and $1 / 800$ with or without $\mathrm{NaOH}$ at a concentration of $0.1 \%$. The mixtures were incubated at room temperature for $30 \mathrm{~min}$. The $\mathrm{J} 1 \mathrm{strain}$ was mixed with an equal volume of alkylbenzyldimethylammonium chloride (ABDAC) [3] or [mono-bis (trimethylammonium-methylene chloride)]-alkyl $\left(\mathrm{C}_{9-15}\right)$ toluene (MBTAMCAT) [4] diluted with distilled water to give the same final concentrations and $\mathrm{NaOH}$ content as DDAC. The experiment conditions were the same as for DDAC. Distilled water controls were used with or without $\mathrm{NaOH}$ at a concentration of $0.1 \%$. Following incubation, the specimens were immediately diluted and titrated.

Effect of DDAC at different temperatures on the virus: The $\mathrm{J} 1$ strain was mixed with an equal volume of DDAC in distilled water to give dilutions of 1/200, 1/400, and 1/800 with or without $0.1 \% \mathrm{NaOH}$. The mixtures were incubated at $4^{\circ} \mathrm{C}$, room temperature (about $20^{\circ} \mathrm{C}$ ), or $40^{\circ} \mathrm{C}$ for $30 \mathrm{~min}$. 
A distilled water control containing $0.1 \% \mathrm{NaOH}$ was used under the same conditions as for DDAC.

Effect of DDAC at various concentrations of $\mathrm{NaOH}$ on the virus: The $\mathrm{J} 1$ strain was mixed with an equal volume of DDAC in distilled water to give a dilution of $1 / 400$ with $\mathrm{NaOH}$ at concentrations of $0 \%, 0.0125 \%, 0.025 \%, 0.1 \%$, $0.2 \%$, and $0.5 \%$. The $\mathrm{pH}$ of each dilution was determined before and after mixing with the virus suspension. Distilled water controls contained the same concentrations of $\mathrm{NaOH}$ as DDAC.

Effect of time of incubation of DDAC with $0.1 \% \mathrm{NaOH}$ on the virus: The $\mathrm{J} 1$ strain was mixed with an equal volume of DDAC at a dilution of $1 / 400$ with $0.1 \% \mathrm{NaOH}$. The mixtures were incubated at room temperature for $1,5,10$, 30 , and $60 \mathrm{~min}$. Distilled water containing $0.1 \% \mathrm{NaOH}$ was used as a control under the same condition as DDAC. A DDAC control without $\mathrm{NaOH}$ was mixed with the virus and incubated for $60 \mathrm{~min}$ at room temperature.

Effect of triton $X-100$ on virus infectivity with or without $0.1 \% \mathrm{NaOH}$ : The $\mathrm{J} 1$ strain was mixed with an equal volume of triton X-100 (0.276 M: adjusted molecular weight as DDAC) diluted with distilled water to give dilutions of $1 /$ $200,1 / 400,1 / 600$, and $1 / 800$ with or without $0.1 \% \mathrm{NaOH}$. The mixtures were incubated at room temperature for 30 min. Distilled water with or without $0.1 \% \mathrm{NaOH}$ as a control was used. The effect of triton X-100 and DDAC with or without $0.1 \% \mathrm{NaOH}$ on SVDV was also examined. The J1 strain was mixed with an equal volume of triton $\mathrm{X}$ 100 at a dilution of $1 / 400$ with $0.1 \% \mathrm{NaOH}, \mathrm{DDAC}$ at a dilution of $1 / 400$ with $0.1 \% \mathrm{NaOH}$, and triton $\mathrm{X}-100$ and DDAC at a concentration of $1 / 200$ each with or without $0.1 \% \mathrm{NaOH}$. Distilled water with or without $0.1 \% \mathrm{NaOH}$ was used as a control under the same conditions as for the above compounds.

Electron microscopy: The J1 strain was propagated and purified for examination by electron microscopy. The virus was purified by the same procedure as before [7]. Briefly, the J1 strain was inoculated onto IBRS-2 cells, and the infectious fluid was harvested $24 \mathrm{hr}$ after inoculation. The clarified infected fluid was centrifuged for $2 \mathrm{hr}$ at 95,000 $\times$ $\mathrm{g}$ at $4^{\circ} \mathrm{C}$ with a $30 \%$ glycerol cushion. The pellet was suspended in TNE (0.01 M Tris- $\mathrm{HCl} \mathrm{pH} 7.4,0.1 \mathrm{M} \mathrm{NaCl}, 1$ $\mathrm{mM}$ disodium EDTA) and banded by isopycnic centrifugation in $\mathrm{CsCl}(\rho=1.34 \mathrm{~g} / \mathrm{m} l)$ for $16 \mathrm{hr}$ at $150,000 \times$ $\mathrm{g}$ at $7^{\circ} \mathrm{C}$. The band of virus was collected and dialyzed against distilled water. The purified viruses were mixed with an equal volume of distilled water, $0.1 \% \mathrm{NaOH}$, a $1 /$ 400 dilution of DDAC, a 1/400 dilution of DDAC with $0.1 \% \mathrm{NaOH}$, a $1 / 400$ dilution of triton $\mathrm{X}-100$ with $0.1 \%$ $\mathrm{NaOH}$, and a $1 / 200$ dilution of DDAC and triton $\mathrm{X}-100$ mixture with $0.1 \% \mathrm{NaOH}$ and allowed to stand for $30 \mathrm{~min}$ at room temperature. One drop of each sample was mounted on a 400-mesh carbon-coated grid, and negatively stained


samples were examined in a JEM-1200 EX electron microscope (JEOL Co., Tokyo, Japan).

\section{RESULTS}

Effects of QACs on SVDV with or without $0.1 \% \mathrm{NaOH}$ : The effects of QACs on SVDV with or without $0.1 \% \mathrm{NaOH}$ are summarized in Table 1 . Both SVDV strains $\mathrm{J} 1$ and $\mathrm{H} /$ 3'76 were inactivated by all dilutions of DDAC with $0.1 \%$ $\mathrm{NaOH}$. However DDAC without $0.1 \% \mathrm{NaOH}$ had no effect on either strain, even at high concentration. ABDAC and MBTAMCAT with $0.1 \% \mathrm{NaOH}$ inactivated the $\mathrm{J} 1$ strain, but the inactivation rates were lower than those of DDAC. ABDAC and MBTAMCAT without $0.1 \% \mathrm{NaOH}$ also had no effect on SVDV. The effects of three QACs with $0.1 \%$ $\mathrm{NaOH}$ were almost the same in $1 / 200$ and $1 / 400$ dilution, but its were lower in $1 / 600$ and $1 / 800$ dilution, respectively. The distilled water control with $0.1 \% \mathrm{NaOH}$ combined with three QACs had little effect on SVDV.

Effects of DDAC with $\mathrm{NaOH}$ on SVDV under different conditions: Based on the results of the effects of QACs on SVDV, DDAC was used for the following other experiments as a representative QAC. The effects of DDAC with $0.1 \%$ $\mathrm{NaOH}$ at different temperatures on the virus are shown in Table 2. At $40^{\circ} \mathrm{C}$ incubation, all dilutions of DDAC with

Table 1. The effects of QACs with or without $0.1 \% \mathrm{NaOH}$ on SVDV

\begin{tabular}{|c|c|c|c|c|}
\hline \multirow[b]{2}{*}{ QAC } & \multirow[b]{2}{*}{ Diluton } & \multirow[b]{2}{*}{$\begin{array}{l}\text { Presence of } \\
0.1 \% \mathrm{NaOH}\end{array}$} & \multicolumn{2}{|c|}{ Virus titers } \\
\hline & & & $\begin{array}{c}\text { Strain } \\
\mathrm{J} 1\end{array}$ & $\begin{array}{c}\text { Strain } \\
\mathrm{H} / 3^{\prime} 76\end{array}$ \\
\hline \multirow[t]{8}{*}{ DDAC } & $\times 200$ & - & 6.78 & 7.00 \\
\hline & $\times 400$ & - & 6.78 & 7.26 \\
\hline & $\times 600$ & - & 6.95 & 7.00 \\
\hline & $\times 800$ & - & 6.90 & 7.00 \\
\hline & $\times 200$ & + & 2.60 & 1.90 \\
\hline & $\times 400$ & + & 2.60 & 2.00 \\
\hline & $\times 600$ & + & 3.11 & 3.04 \\
\hline & $\times 800$ & + & 3.11 & 3.60 \\
\hline \multirow[t]{2}{*}{ Control } & & - & 6.90 & 7.30 \\
\hline & & + & 6.95 & 5.70 \\
\hline \multirow[t]{8}{*}{ ABDAC } & $\times 200$ & - & 7.00 & \\
\hline & $\times 400$ & - & 7.00 & \\
\hline & $\times 600$ & - & 7.00 & \\
\hline & $\times 800$ & - & 7.00 & \\
\hline & $\times 200$ & + & 2.90 & \\
\hline & $\times 400$ & + & 4.30 & \\
\hline & $\times 600$ & + & 4.40 & \\
\hline & $\times 800$ & + & 4.60 & \\
\hline \multirow[t]{2}{*}{ Control } & & - & 7.15 & \\
\hline & & + & 6.00 & \\
\hline \multirow[t]{8}{*}{ MBTAMCAT } & $\times 200$ & - & 7.08 & \\
\hline & $\times 400$ & - & 7.20 & \\
\hline & $\times 600$ & - & 7.28 & \\
\hline & $\times 800$ & - & 7.30 & \\
\hline & $\times 200$ & + & 3.70 & \\
\hline & $\times 400$ & + & 3.60 & \\
\hline & $\times 600$ & + & 4.78 & \\
\hline & $\times 800$ & + & 4.90 & \\
\hline \multirow[t]{2}{*}{ Control } & & - & 7.32 & \\
\hline & & + & 6.60 & \\
\hline
\end{tabular}

Virus titer is indicated as $\log 10 \mathrm{PFU}$ per $0.1 \mathrm{~m} l$ of the samples. 
$0.1 \% \mathrm{NaOH}$ had a strong effect on SVDV strain $\mathrm{J} 1$, and viruses were not detected at high concentrations of the drug ( $1 / 200$ and $1 / 400$ dilutions). At $20^{\circ} \mathrm{C}$ (room temperature) incubation, the effect of DDAC was moderate, and it was strong at high concentrations (1/200 and 1/400 dilutions). At $4^{\circ} \mathrm{C}$ incubation, the effect of DDAC was weaker than at $40^{\circ} \mathrm{C}$ and $20^{\circ} \mathrm{C}$, and there was no effect at the lowest concentration (1/800 dilution).

The effects of DDAC at various concentrations of $\mathrm{NaOH}$ on the virus are summarized in Table 3 . When the DDAC contained $\mathrm{NaOH}$ even at low concentration, it inactivated the virus, and the effect was stronger at high concentration $(0.1 \%, 0.2 \%$, and $0.5 \%)$. However, the distilled water control had no effect at low concentrations of $\mathrm{NaOH}$ $(0.0125 \%$ and $0.025 \%)$. A strong inactivating effect on the virus was also observed when the concentration of $\mathrm{NaOH}$ was $0.1 \%$ or higher. The effect on the virus was generally stronger in DDAC solution than in distilled water solution.

The effects of incubation time of DDAC with $0.1 \%$ $\mathrm{NaOH}$ on virus infectivity are shown in Table 4. A strong effect of DDAC with $0.1 \% \mathrm{NaOH}$ on SVDV was already observed after $1 \mathrm{~min}$ of incubation. And the effect appeared slightly higher until $60 \mathrm{~min}$ of incubation, whereas, the complete effect of $0.1 \% \mathrm{NaOH}$ on SVDV appeared after 30 min of incubation, and it was lower than that of DDAC.

Effects of triton $\mathrm{X}-100$ with or without $0.1 \% \mathrm{NaOH}$ on $S V D V$ : The effects of triton X-100 with or without $0.1 \%$ $\mathrm{NaOH}$ on SVDV were compared with those of QACs. The effects of triton $\mathrm{X}-100$ with $0.1 \% \mathrm{NaOH}$ were slight at dilutions of $1 / 200,1 / 400$, and $1 / 600$ (data not shown). The effects of the mixture of triton X-100 and DDAC with $0.1 \% \mathrm{NaOH}$ on SVDV were smaller than those of DDAC alone. The effects of DDAC were inhibited by triton X-100 (Table 5).

Electron microscopy: Electron micrographs of virus particles affected by the compounds are shown in Figs. 1 and 2. Spherical particles about $28 \mathrm{~nm}$ in diameter were observed in many place (Fig. 1-a). These particles were destroyed by $0.1 \% \mathrm{NaOH}$ (Fig. 1-b). The virus particles were gathered by a 1/400 dilution of DDAC (Fig. 1-c). Non-structural substances were observed in many places in the material treated by a $1 / 400$ dilution of DDAC with $0.1 \%$ $\mathrm{NaOH}$ (Fig. 1-d). These substances were considered to be the micelles which were constructed from the viral particles destroyed by DDAC.

Non-structural substances shaped like destroyed viral particles were observed in many places in the material treated by a $1 / 400$ dilution of triton $\mathrm{X}-100$ with $0.1 \% \mathrm{NaOH}$ (Fig. 2-a). These substances were observed also in the material treated by a $1 / 200$ dilution of triton X-100 and DDAC with $0.1 \% \mathrm{NaOH}$. In this material, the substances which were observed in samples treated with DDAC with $0.1 \% \mathrm{NaOH}$ were also observed, but there were fewer of them (Fig. 2-b). The substances shaped like destroyed viral particles were considered to be the micelles which were constructed from viral particles destroyed by triton X-100.
Table 2. Effects of temperature of DDAC with $0.1 \% \mathrm{NaOH}$ on SVDV

\begin{tabular}{lccc}
\hline & \multicolumn{3}{c}{ Virus titer at temperature } \\
Dilution & $4^{\circ} \mathrm{C}$ & $20^{\circ} \mathrm{C}$ & $40^{\circ} \mathrm{C}$ \\
\hline$\times 200$ & 3.48 & 2.85 & $1>$ \\
$\times 400$ & 3.70 & 2.78 & $1>$ \\
$\times 800$ & 7.30 & 3.78 & 2.11 \\
Distilled water & 7.38 & 6.48 & 4.48 \\
\hline
\end{tabular}

The virus titer is indicated as $\log 10 \mathrm{PFU}$ per $0.1 \mathrm{~m} l$ of the sample. SVDV strain J1 was used.

Table 3. Effects of $\mathrm{pH}$ of DDAC at various concentrations of sodium hydroxide on SVDV

\begin{tabular}{llrlc}
\hline Material & $\mathrm{NaOH}(\%)$ & \multicolumn{2}{c}{$\mathrm{pH}^{\mathrm{a})}$} & Virus titer $^{\mathrm{b})}$ \\
\hline 1/400 DDAC & 0 & 7.32 & $(8.28)$ & 7.30 \\
& 0.0125 & 8.27 & $(11.34)$ & 6.95 \\
& 0.025 & 8.89 & $(11.68)$ & 6.95 \\
& 0.1 & 10.85 & $(12.26)$ & 2.00 \\
& 0.2 & 11.88 & $(12.53)$ & $1>$ \\
Distilled water & 0.5 & 12.49 & $(12.86)$ & $1>$ \\
& 0.0125 & 7.32 & $(7.47)$ & 7.30 \\
& 0.025 & 8.14 & $(11.36)$ & 7.26 \\
& 0.1 & 10.78 & $(11.69)$ & 7.32 \\
& 0.2 & 1.86 & $(12.50)$ & 6.30 \\
& 0.5 & 12.49 & $(12.84)$ & 3.00 \\
& & &
\end{tabular}

a) The numbers indicate the $\mathrm{pH}$ of mixed samples. The $\mathrm{pH}$ of the original material is shown in parentheses.

b) Virus titer is indicated as $\log 10 \mathrm{PFU}$ per $\mathrm{m} l$ of the sample. SVDV strain $\mathrm{J} 1$ was used.

Table 4. Effects of time of incubation of DDAC with $0.1 \% \mathrm{NaOH}$ on SVDV

\begin{tabular}{lcc}
\hline Material & Time (minute) & Virus titer \\
\hline $0.1 \% \mathrm{NaOH}$ & 1 & 7.00 \\
& 5 & 7.11 \\
& 10 & 7.04 \\
& 30 & 5.00 \\
$1 / 400 \mathrm{DDAC}$ with $0.1 \% \mathrm{NaOH}$ & 60 & 4.78 \\
& 1 & 2.90 \\
& 5 & 2.70 \\
$1 / 400 \mathrm{DDAC}$ & 10 & 2.11 \\
& 30 & 1.48 \\
& 60 & 1.00 \\
& 60 & 7.08 \\
\hline
\end{tabular}

Virus titer is indicated as $\log 10 \mathrm{PFU}$ per $0.1 \mathrm{~m} l$ of the sample. SVDV strain J1 was used.

\section{DISCUSSION}

QACs are very common disinfectants, and are widely used in the medical field and animal hygiene because they have low toxicity and are non-corrosive to metals [6]. However, QACs have a limited spectrum of activity and are ineffective against most viruses, mycobacteria and bacterial spores [6]. Among viruses, QACs are effective only against 
Table 5. Effects of triton $\mathrm{X}-100$ and DDAC with $0.1 \% \mathrm{NaOH}$ on SVDV

\begin{tabular}{lcc}
\hline Material & $\begin{array}{c}\text { Presence of } \\
0.1 \% \text { NaOH }\end{array}$ & Virus titer \\
\hline 1/400 Triton X-100 & + & 4.15 \\
1/400 DDAC & + & 1.48 \\
1/200 Triton X-100 with 1/200 DDAC & + & 3.23 \\
& - & 6.95 \\
Distilled water & - & 7.00 \\
& + & 4.28 \\
\hline
\end{tabular}

Virus titer is indicated as $\log 10 \mathrm{PFU}$ per $0.1 \mathrm{~m} l$ of the sample. SVDV strain J1 was used.

enveloped viruses (group A) [6,9].

SVDV belongs to the enteroviruses (group B, small nonenveloped virus) [11] and are normally resistant to QACs [2]. However, our results showed that the QACs plus a small amount of $\mathrm{NaOH}$ inactivated SVDV, indicating that the activity of the QACs was enhanced by $0.1 \% \mathrm{NaOH}$. The mechanism of the effect of the QACs (especially DDAC) on SVDV was considered to be as follows. The viral particles of SVD are considered to be solid enough to prevent the effect of QACs alone (Fig. 1-C), whereas they were considered to become fragile and partially destroyed in alkaline condition (high $\mathrm{pH}$ ) (Fig. 1-b). Although the effect of alkali alone in low concentration of $\mathrm{NaOH}$ was weak, the viral particles in alkali became very sensitive to the effect of QACs, as shown in Table 4. The effect of alkali on SVDV appeared very slowly, but that of DDAC with $0.1 \% \mathrm{NaOH}$ appeared immediately. The partially destroyed viral particles formed micelles in response to DDAC (Fig. 1-d), and the infectivity of viral particles was considered to be lost by this micelle formation. This phenomenon also occurred in the case of triton $\mathrm{X}-100$. But the effect of triton $\mathrm{X}-100$ with $0.1 \% \mathrm{NaOH}$ was smaller than that of DDAC. The cause of this was considered to be the difference of the ability of micelle formation between two detergents. The shape of micelles formed by triton X100 (Fig. 2-a) was almost the same as that of the viral particles destroyed by alkali (Fig. 1-b), while those destroyed by DDAC seemed to be of a uniform sturdy shape (Fig. 2-c).

From these results and our previous study [13], QACs with $0.1 \% \mathrm{NaOH}$ are considered to be very effective against the viruses belong to group B and C (small non-enveloped and other non-enveloped viruses) [11]. Therefore, we believe that the QACs are useful disinfectants against viral diseases, when they are used with $0.1 \% \mathrm{NaOH}$. An alkali such as $1 \% \mathrm{NaOH}$ usualy used for disinfection is very dangerous for the human body, but $\mathrm{NaOH}$ at a $0.1 \%$ (final concentration of $0.05 \%$ in our experiments) concentration, is safe for the human body when used for alkalization of QACs [12]. In conclusion, QACs with $0.1 \% \mathrm{NaOH}$ were effective against SVDV(enterovirus), further studies of QACs with $0.1 \% \mathrm{NaOH}$ against other non-enveloped viruses reveal the usefulness of this disinfectant. And, we hope this method will be applied widely in the animal hygiene and medical field.

ACKNOWLEDGEMENTS. The authors thank Dr. Y. Kono for critical reading of the manuscript, and Dr. Y. Murakami for technical suggestions of an electron microscope.

\section{REFERENCES}

1. Angele, M. H. 1975. Oberflachenakitivitat, mikrogielle Wirksamkeit und Anwendung von ausgewahlten TeraalkylStickstoffverbindungen. Seifen-Ole-Fette-Wachse. 101: 273-277 (in German with English summary).

2. Blackwell, J. H., Graves, J. H., and McKercher, P. D. 1975. Chemical inactivation of swine vesicular disease virus. $\mathrm{Br}$. Vet. J. 131: 317-323.

3. Domagk, G. 1935. Eine neue Klasse von Desinfectionsmitteln. Dtsch. Med. Ochenschr. 24: 829-832.

4. Finnegan, J. K., Larson, P. S., Blackwell, S. R. Jr., Haag, H. B., Douglas, E. J., and Dreyfuss, M.L. 1953. Pharmacologic observations on two quaternary ammonium germicides. $J$. Pharmacol. Exp. Ther. 109: 422-430.

5. Herniman, K. A. J., Medhurst, M., Wilson, J. N., and Sellers, R. F. 1973. The action of heat, chemicals and disinfectants on swine vesicular disease virus. Vet. Rec. 93: 620-624.

6. Jefferey, D. J. 1995. Chemicals used as disinfectants: active ingredients and enhancing additives. Rev. Sci. Tech. Off. Int. Epiz. 14: 57-74.

7. Kanno, T., Inoue, T., Wang, Y., Sarai, A., and Yamaguchi, S. 1995. Identification of the location of antigenic sites of swine vesicular disease virus with neutralization- resistant mutants. J. Gen. Virol. 76: 3099-3106.

8. Kodama, M., Ogawa, T., Saito, T., Tokuda, G., Sasahara, J., and Kumagai, T. 1980. Swine vesicular disease virus isolated from healthy pigs in non-epizootic period. I. Isolation and identification. Natl. Inst. Anim. Health Q. 20: 1-10.

9. Maris, P. 1995. Modes of action of disinfectants. Rev. Sci. Tech. Off. Int. Epiz. 14: 47-55.

10. Nardelli, L., Lodetti, E., Gualandi, G. L., Burrows, R., Goodridge, D., Brown, F., and Cartwright, B. 1968. A foot and mouth disease syndrome in pigs caused by an enterovirus. Nature 219: 1275-1276.

11. Noll, H. and Younger, J. S. 1959. Virus-lipid interactions. The mechanism of adsorption of lipophilic viruses to water insoluble polar lipids. Virology. 8: 319-343.

12. Seki, R., Kamimura, R., Mitsubayashi, S., Shirai, J., Nitta, M., and Takatori, K. 1992. Itentified effects of the cationic disinfectant alkalized with $\mathrm{NaOH}$ against microorganisms. Bull. Anim. Hyg. 36: 7-18 (in Japanese with English summary).

13. Shirai, J., Seki, R., Kamimura, R., and Mitsubayashi, S. 1994. Effects of invert soap with $0.05 \%$ sodium hydroxide on infectious bursal disease virus. Avian Dis. 38: 240-243.

14. Tokuda, G., Tokui, T., Khono, M., Nakagawa, T., Kumagai, T., and Sasahara, J. 1975. Experimental infection of pigs with swine vesicular disease virus isolated in Japan. Bull. Natl Inst. Anim. Health 70: 19-26 (in Japanese with English summary).

15. Watson, W. A. 1981. Swine vesicular disease in Great Britain. Can. Vet. J. 22: 195-200. 




Fig. 1. Electron micrographs of the effects of DDAC on SVDV. a) SVDV purified with an equal amount of distilled water, b) SVDV purified with an equal amount of $0.1 \% \mathrm{NaOH}$, c) SVDV purified with an equal amount of a 1/400 dilution of DDAC, d) SVDV purified with an equal amount of a $1 / 400$ dilution of DDAC with $0.1 \% \mathrm{NaOH}$. Bar indicates $100 \mathrm{~nm}$. 


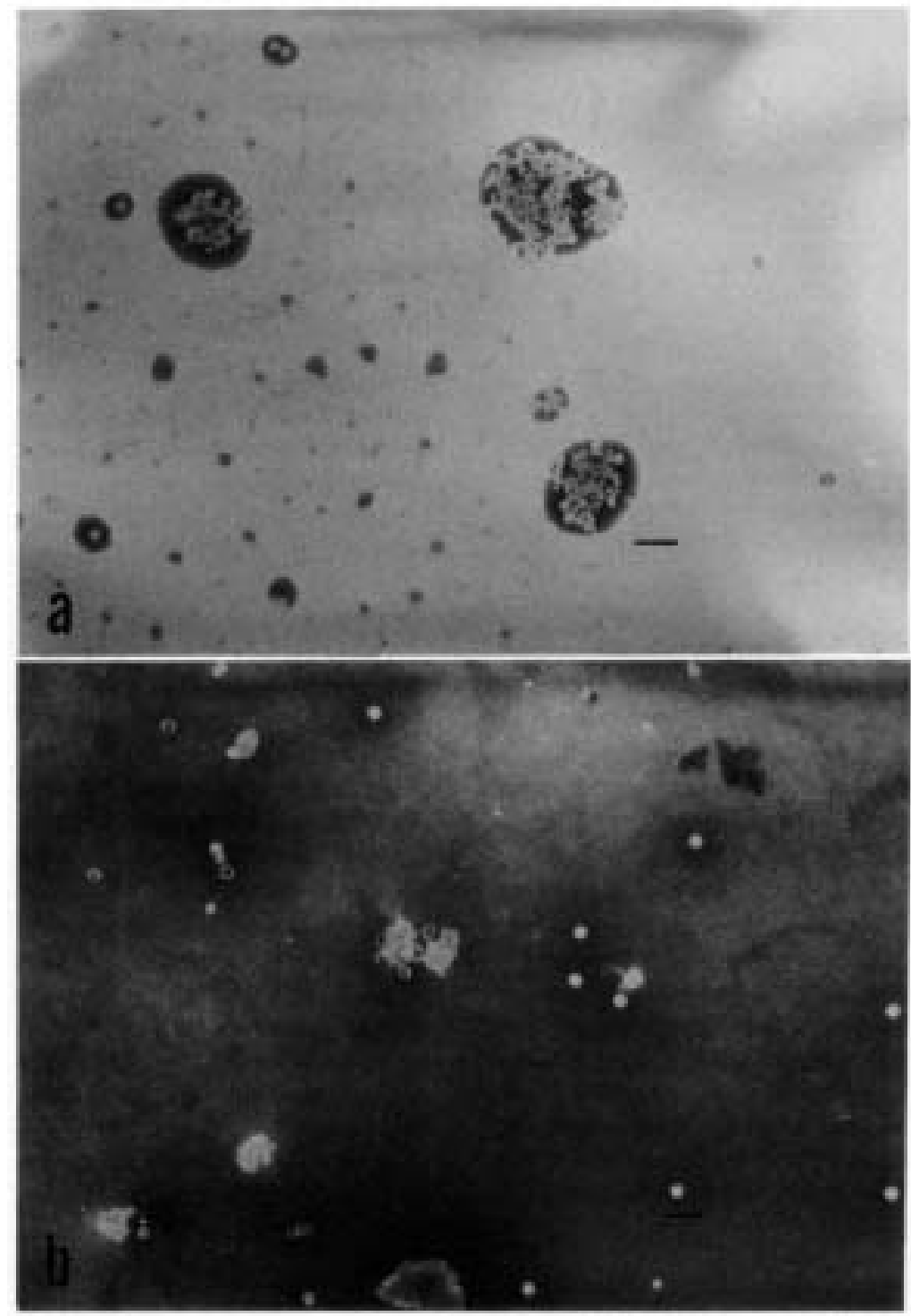

Fig. 2. Electron micrographs of the effects of triton X-100 and DDAC on SVDV. a) SVDV purified with an equal amount of a $1 / 400$ dilution of triton $X-100$ with $0.1 \% \mathrm{NaOH}, \mathrm{b}) \mathrm{SVDV}$ purified with an equal amount of a 1/200 dilution of triton $\mathrm{X}-100$ and DDAC with $0.1 \% \mathrm{NaOH}$. Bar indicates $100 \mathrm{~nm}$. 